\title{
練習船「豊潮丸」の横傾斜時における操縱性能
}

\author{
松本 隼人 1 平田 法隆 2 安川 宏紀

\section{Maneuverability of a Training Ship "Toyoshio-Maru" in Heeled Condition}

\author{
Hayato MATSUMOTO, Noritaka HIRATA and Hironori YASUKAWA
}

\begin{abstract}
It is well known that the heel affects the ship maneuverability significantly, however there is no quantitative evidence on the maneuvering motions of full-scale ships so far. To capture the heel effect on the ship maneuverability, full-scale trials were carried out using a training ship "Toyoshio-Maru" of Faculty of Applied Biological Science, Hiroshima University, Japan. Zig-zag test and turning test were conducted in 4 different heeled conditions. Motion measurement was performed using a K-GPS (Kinematic GPS) system with 3 antennas placed on the ship. The heel angle $\phi$ was varied as $3.5,-0.4,-1.5$, and -5.6 degrees. Negative $\phi$ means the heel to port side. In case that the azimuth angle was -10 degrees, the turning circles become large with increasing the heel angle to port side. In case that the azimuth angle was 10 degrees, on the other hand, the turning circles become small with increasing the heel angle. The heel angle increase to the port side is corresponding to the azimuth angle increase to positive direction. In case of the present ship "Toyoshio-Maru", -2 degrees of the heel angle is equivalent to almost 1 degree of the azimuth angle.

Thus, the heel effect on the ship maneuvering motions was successfully captured in full-scale trials.
\end{abstract}

Keywords : maneuverability, heel, K-GPS, full-scale trials

キーワード: 操縦性、横傾斜、K-GPS、実船試験

\section{1. 緒 言}

荷崩れや外板損傷等が原因で船体が横傾斜する と、船体の左右対称性が壊れ、操縦性能に大きな影 響を及ぼすことがある。そのような横傾斜が起こっ た際の操縦性能を知ることは、海難事故防止への一 助になると考えられる。

横傾斜しながら航行する船の操縦性能について は、流体力特性を把握するための拘束模型試験をべ 一スとした安川・平田の研究例 ${ }^{(1)}$ があるが、横傾斜 する船の操縦運動特性を実船試験において計測し、 定量的に把握した例はないように思われる。
一方で、近年では GPS 技術の発達により、船の操 縦運動を高精度で計測することが可能となっている。 本研究では、K-GPS ${ }^{(2)}$ を用いて、Table 1 に示寸主要 目を持つ広島大学生物生産学部の練習船「豊潮丸」

(3)を対象に、横傾斜時にはどの様な操縦運動特性を

Table 1 Principal dimensions of "Toyoshio-Maru"

\begin{tabular}{|c|c|}
\hline$L_{O A}(\mathrm{~m})$ & 40.50 \\
\hline$L_{P P}(\mathrm{~m})$ & 35.50 \\
\hline$B_{\text {mld }}(\mathrm{m})$ & 8.50 \\
\hline$D_{\text {mld }}(\mathrm{m})$ & 3.70 \\
\hline$V_{S}(\mathrm{~m} / \mathrm{s})$ & 5.40 \\
\hline
\end{tabular}




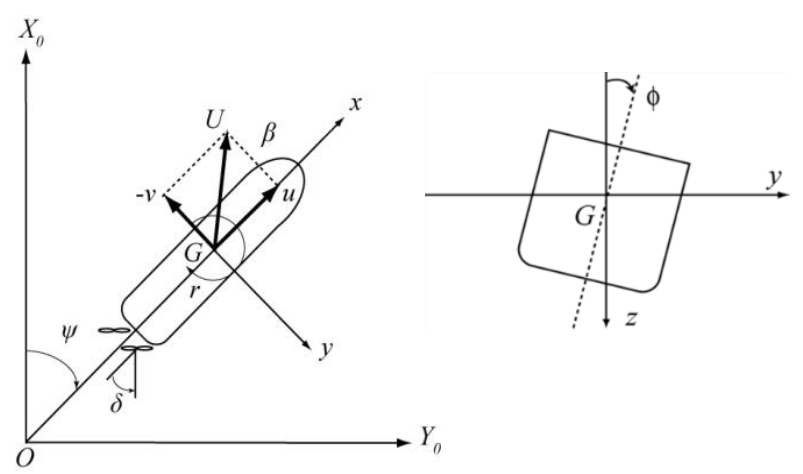

Fig. 1 Coordinate systems

示すのか、を把握するため実船試験を行った。なお、 「豊潮丸」はバトックフロー船型を採用した電気推 進船であり、舵は持たず、首振り式の推進・操舵装 置 2 基を用いて操船する。

\section{2. 座標系}

Fig. 1 に使用する座標系を示す。空間固定系 $O-X_{0} Y_{0} Z_{0}$ と船体水面固定座標系 $G-x y z$ の二つの座標 系を考える。原点は試験開始時における船の重心位 置にとり, その時の船の船首方向に $x$ 軸、横方向に $y$ 軸、鉛直下向きに $z$ 軸をとる。 $X_{0}$ 軸に対して $x$ 軸 のなす角を回頭角 $\psi$ とする。また、ロール角を $\phi$ と し、船を後方から見た時、時計回りの回転方向を正 とする。 $\delta$ は首振り式の推進 ・操舵装置の首振り角 であり、左右舷で同じ角度をとることとする。この 船は舵を搭載していない。船体固定系の $x$ 軸、 $y$ 軸 方向の速度成分を $u 、 v$ とし、 $z$ 軸まわりの回頭角速 度を $r$ とする。

\section{3. 海上試験の概要 \\ 3.1 試験の概要}

海上試験は直進航行試験、旋回試験、Zig-Zag 試験 (以後 Z 試験) の三種類を行った。CPP の翼角は $B A=16 \mathrm{deg}$ と一定に保ち、「豊潮丸」の横傾斜角を $\phi=+3.5 \mathrm{deg},-0.4 \mathrm{deg},-1.5 \mathrm{deg},-5.6 \mathrm{deg}$ の四種類に変更 させて試験を実施し、それらの結果を比較すること で横傾斜の影響を把握した。各試験の詳細を Table 2 に示す。直進航行試験とは、横傾斜角がついた状態

Table 2 Trial conditions

\begin{tabular}{|c|c|}
\hline $\begin{array}{l}\text { Straight moving test } \\
\text { with heel }\end{array}$ & $\begin{array}{l}\text { Keeping } \delta=0 \text {, } \\
\text { Using autopilot }\end{array}$ \\
\hline $\begin{array}{l}\text { Turning test with heel } \\
\phi=+3.5,-1.5,-5.6 \mathrm{deg}\end{array}$ & $\delta= \pm 10 \mathrm{deg}, \pm 35 \mathrm{deg}$ \\
\hline $\begin{array}{l}\text { Turning test without } \\
\text { heel }(\phi=-0.4 \mathrm{deg})\end{array}$ & $\begin{array}{c}\delta= \pm 5 \mathrm{deg}, \quad \pm 10 \mathrm{deg} \\
\pm 20 \mathrm{deg}, \pm 35 \mathrm{deg}\end{array}$ \\
\hline Zig-zag test & $\delta / \psi= \pm 10 \mathrm{deg}, \pm 20 \mathrm{deg}$ \\
\hline
\end{tabular}

で、直進航行するときの操縦運動を計測するもので あり、首振り角は Odeg とした場合とオートパイロッ 卜を使用した場合の二つを実施した。できるだけ外 乱影響を排除するために $0.926 \mathrm{~km}$ の航路を往復した。 船速の平均は $4.4 \mathrm{~m} / \mathrm{s}$ であった。

\section{2 試験状態}

Table 3 に海上試験における船の載荷状態と環境 状況を示す。2012 年 5 月 16 日に $\phi=-1.5 \mathrm{deg},-5.6 \mathrm{deg}$ の試験を、2012 年 5 月 17 日に $\phi=+3.5 \mathrm{deg},-0.4 \mathrm{deg} の$ 試験を実施した。試験は瀬戸内海の宮島南沖で実施 した。両日とも風・波ともに稳やかであった。

Fig. 2 に K-GPS アンテナと重りの設置位置を示す。 K-GPS アンテナを三基、基線長前後 $5 \mathrm{~m}$ 、左右 $9 \mathrm{~m}$ に なるように設置し、本船の位置と姿勢の計測を行っ

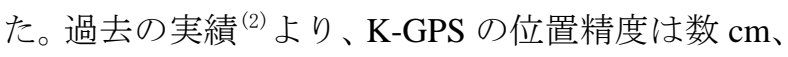
方位精度はアンテナ間の基線長から roll が $0.2 \mathrm{deg}$ 程 度、yaw が $0.1 \mathrm{deg}$ 程度であったと見込まれる。横傾 斜は、別途、高さ $1,410 \mathrm{~mm} \times$ 幅 $1,010 \mathrm{~mm} \times$ 長さ $1,220 \mathrm{~mm}$ 、

Table 3 Ship loading conditions and environmental conditions in trials

\begin{tabular}{|l|c|c|}
\hline Date & May 16 & May 17 \\
\hline Displacement $W\left(\mathrm{~m}^{3}\right)$ & 561.61 & 559.30 \\
\hline Fore draft $d_{f}(\mathrm{~m})$ & 2.45 & 2.50 \\
\hline Aft draft $d_{a}(\mathrm{~m})$ & 3.05 & 3.00 \\
\hline Trim $(\mathrm{m})$ & 0.48 & 0.46 \\
\hline GM $(\mathrm{m})$ & 0.68 & 0.68 \\
\hline Weather & Partly cloudy & Sunny \\
\hline Wind direction & SSW & SSE \\
\hline Wind speed $(\mathrm{m} / \mathrm{s})$ & $0.1 \sim 9.0$ & $0.1 \sim 3.0$ \\
\hline
\end{tabular}

GPS antennas $\square$ Weight $(\phi=-1.5 \mathrm{deg},-5.6 \mathrm{deg})$

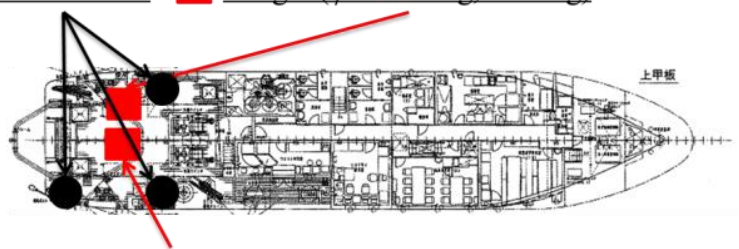

Weight $(\phi=+3.5 \mathrm{deg},-0.4 \mathrm{deg})$

Fig. 2 Position of GPS antennas and block weights

Table 4 Test condition of block weight and water weight in freshwater tank

\begin{tabular}{|c|c|c|c|c|c|}
\hline \multirow{2}{*}{ Date } & \multirow{2}{*}{$\phi(\mathrm{deg})$} & \multicolumn{2}{|c|}{$\begin{array}{c}\text { Block weight } \\
\text { position }(\mathrm{m})\end{array}$} & \multicolumn{2}{c|}{$\begin{array}{c}\text { Freshwater tank } \\
\left(\mathrm{m}^{3}\right)\end{array}$} \\
\cline { 3 - 6 } & & $x$ & $y$ & $\begin{array}{c}\text { Left } \\
\text { side }\end{array}$ & $\begin{array}{c}\text { Right } \\
\text { side }\end{array}$ \\
\hline May 17 & +3.5 & -14.80 & 0 & 0 & 12 \\
\hline May 17 & -0.4 & -14.80 & 0 & 6 & 6 \\
\hline May 16 & -1.5 & -14.80 & -2.25 & 6.5 & 6.5 \\
\hline May 16 & -5.6 & -14.80 & -2.25 & 13 & 0 \\
\hline
\end{tabular}


重さ4040kgの重りを1個特別に用意して甲板に配置 し、重さ約 6000kg の清水タンク内の水を移動させる ことによって実現した。

Table 4 に重りと清水タンクの水の横傾斜との関 係を示す。清水タンクの水が減るのは、試験期間中 に船員の生活用水として使用したためである。

\section{4. 試験結果}

\section{1 直進航行試験}

Fig. 3 に各横傾斜状態における航跡のグラフを示 す。保針操作は行わず、首振り角 Odeg での結果であ る。黒色の航跡は横傾斜角がほぼ Odeg であるにも関 わらず、右舷側に回頭しており、理由は不明だが、 本船はそのような特性を持つことが分かる。右舷側 に横傾斜が付いた状態で前進すると左舷側に回頭し、 一方、左舷側に横傾斜が付いた状態で前進すると右 舷側に回頭することが明確に見て取れる。また、Fig. 4 に横傾斜に対する定常旋回時の回頭角速度を示す。 その傾向は、横傾斜角の大きさとほぼ線形関係にあ る。図中、平均線を入れている。傾きが負であるこ とから、右舷側に横傾斜が付いた状態で前進すると 左舷側に回頭することがわかる。このような傾向は、 安川・平田が指摘したもの ${ }^{(1)}$ と一致している。

Fig. 5 にオートパイロットを用いて直進した際 の保針操作量 (首振り角) の平均を示す。横軸が横傾 斜角、縦軸が当て舵の大きさを表す。参考のために

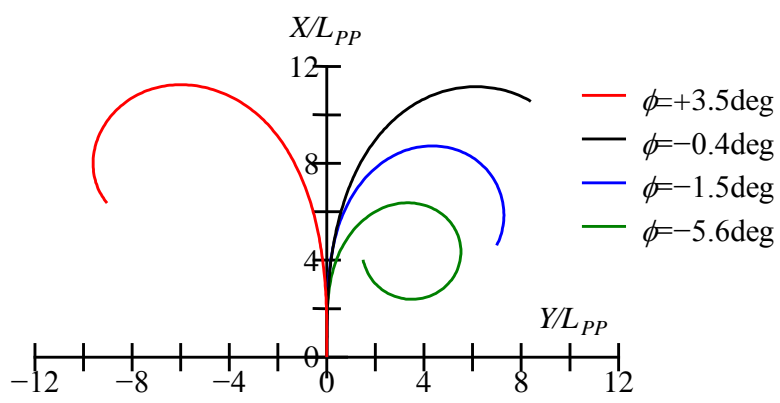

Fig. 3 Ship trajectories in straight moving test with heel $\delta=0 \mathrm{deg}$

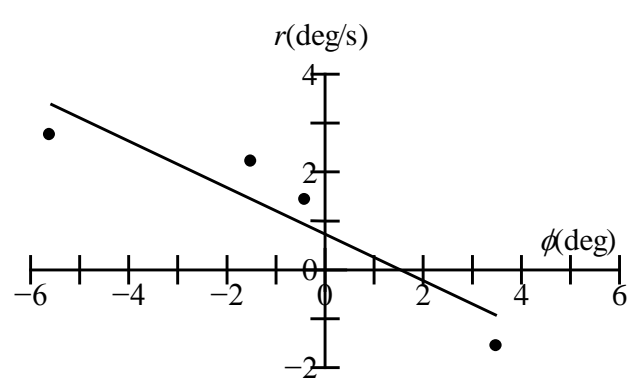

Fig. 4 Steady turning yaw rate in straight moving test with heel $\delta=0 \mathrm{deg}$

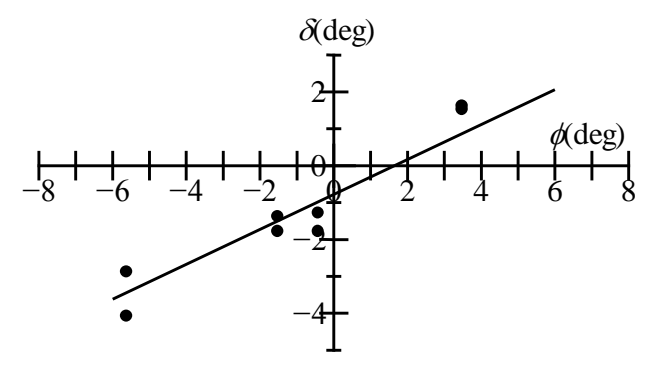

Fig. 5 Offset azimuth angle to keep the course in heeled conditions

記入した近似直線は右肩上がりになっている。これ は、右舷側に横傾斜が付くほど左舷側に回頭しよう とするので、右舷側に回頭する方向に首振り角を取 っていることを表している。図から、横傾斜角 Odeg のときの保針操作量 (首振り角) は約-0.7deg であり、 右舷側に約 $1.6 \mathrm{deg}$ 横傾斜を付けると、保針操作量 (首 振り角) は Odeg となることが分かる。また、近似直 線の傾きから、保針操作量 (首振り角) は横傾斜角の およそ 0.5 倍必要であることが分かる。すなわち、 本船の横傾斜角 2 deg は、首振り角約-1deg に相当す

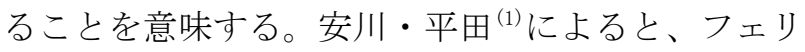
一船型の場合、横傾斜角 $3 \mathrm{deg}$ が、舵角約-1deg に相 当するとしている。そのフェリーと比較すると、本 船は横傾斜に対してヨー運動が誘起されやすいこと が分かる。

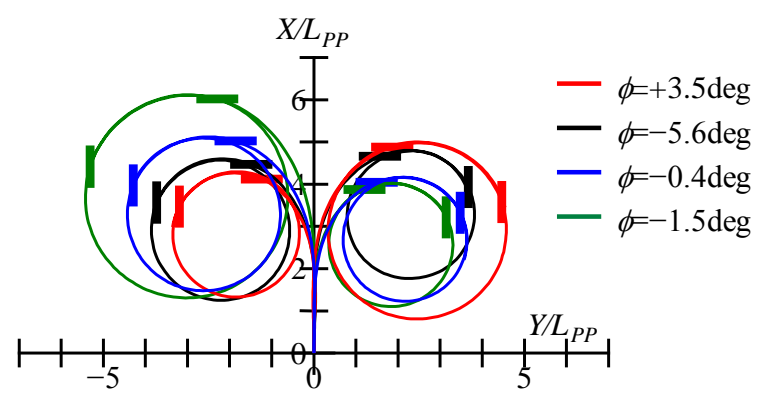

Fig. 6 Comparison of turning trajectories for various heel angles $(\delta= \pm 10 \mathrm{deg})$

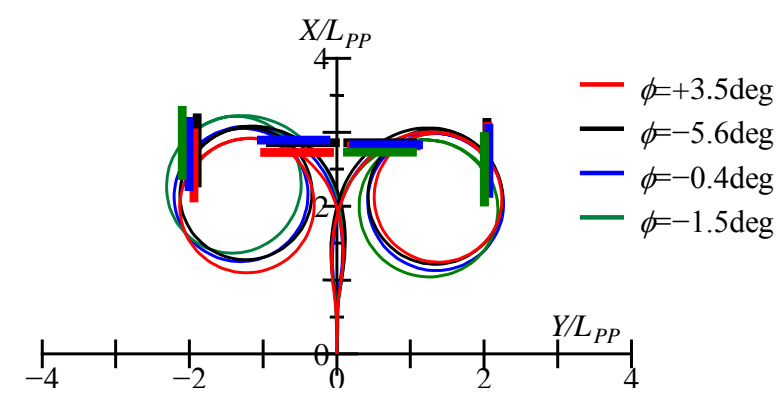

Fig. 7 Comparison of turning trajectories for various heel angles $(\delta= \pm 35 \mathrm{deg})$ 


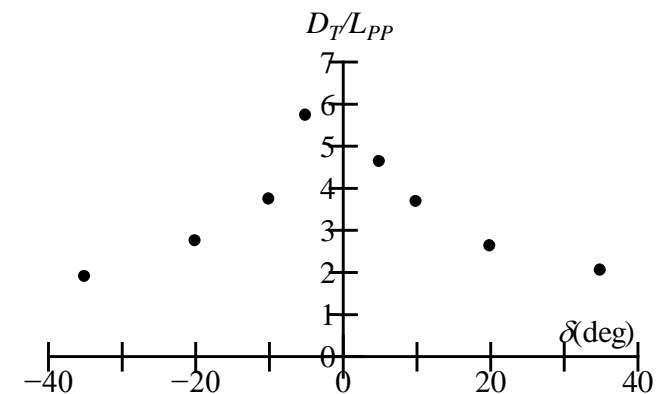

Fig. $8 D_{T} / L_{p p}$ in turning tests versus azimuth angle $(\phi=-0.4 \mathrm{deg})$

\section{2 旋回試験}

旋回試験では、旋回縦距(以後 $A_{D} / L_{P P}$ ) と旋回圈(以 後 $\left.D_{I} / L_{P P}\right)$ によって旋回性能の評価を行う。旋回航跡 については、文献 ${ }^{(3)} に$ 示した方法で、旋回航跡にお ける潮流によるドリフトの補正を行っている。

Fig. 6 に $\delta= \pm 10 \mathrm{deg}$ の旋回航跡を示す。図中の太線 は $A_{D} / L_{P P}$ と $D_{T} / L_{P P}$ の二つの位置を示している。左舷 側に回頭する $\delta=-10 \operatorname{deg}$ の旋回航跡に注目寸ると、横 傾斜角が小さくなるほど、 $A_{D} / L_{P P}$ と $D_{T} / L_{P P}$ が大きく なる。一方、右舷側に回頭する $\delta=+10 \mathrm{deg}$ の旋回航 跡に注目すると、横傾斜角が小さくなるほど、 $A_{D} / L_{P P}$ と $D_{T} / L_{P P}$ が小さくなっており、 $\delta=-10 \mathrm{deg}$ の旋回とは 逆の特徵が表れている。

Fig. 7 に $\delta= \pm 35 \mathrm{deg}$ の旋回航跡を示す。Fig. 6 と比 較して、 $A_{D} / L_{P P}$ と $D_{T} / L_{P P}$ の位置が重なっているよう

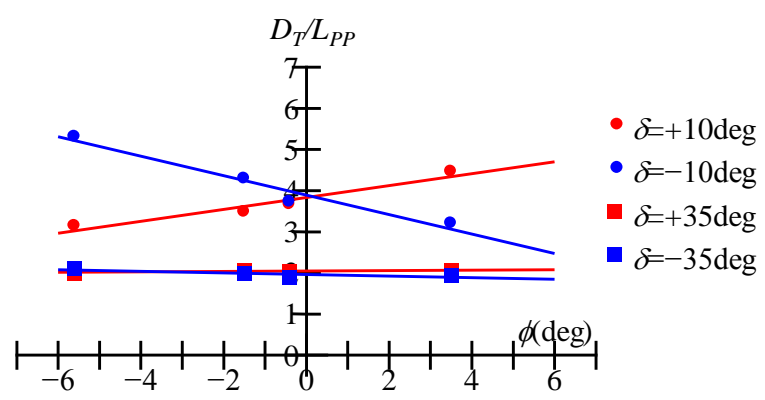

Fig. $9 D_{T} / L_{p p}$ in turning tests versus heel angle

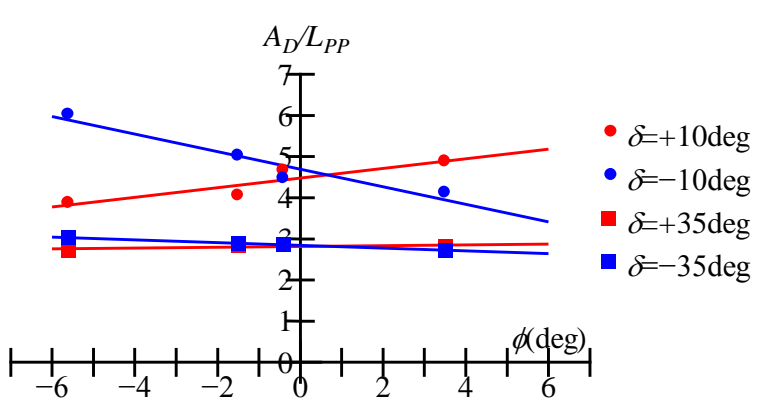

Fig. $10 A_{D} / L_{p p}$ in turning tests versus heel angle
に見えるが、左舷側に回頭する $\delta=-35 \mathrm{deg}$ の旋回航跡 では、横傾斜角が小さくなるほど、 $A_{D} / L_{P P}$ と $D_{T} / L_{P P}$ が大きくなっており、一方、右舷側に回頭する $\delta=+35 \mathrm{deg}$ の旋回航跡では、横傾斜角が小さくなるほ ど、 $A_{D} / L_{P P}$ と $D_{T} / L_{P P}$ が小さくなっており、Fig. 6 の 結果と定性的には同じである。ただし、Fig. 6 の結 果のように、横傾斜角の影響は顕著ではない。

本船の横傾斜角 $2 \mathrm{deg}$ は、首振り角約-1deg に相当す ると述べたが、左舷側に回頭した場合、 $\phi=+3.5 \mathrm{deg}$ 旋回航跡（赤）が約 37deg 旋回、 $\phi=-5.6 \mathrm{deg}$ 旋回航跡 (緑) が約 32deg 旋回の航跡に相当すると考えられ
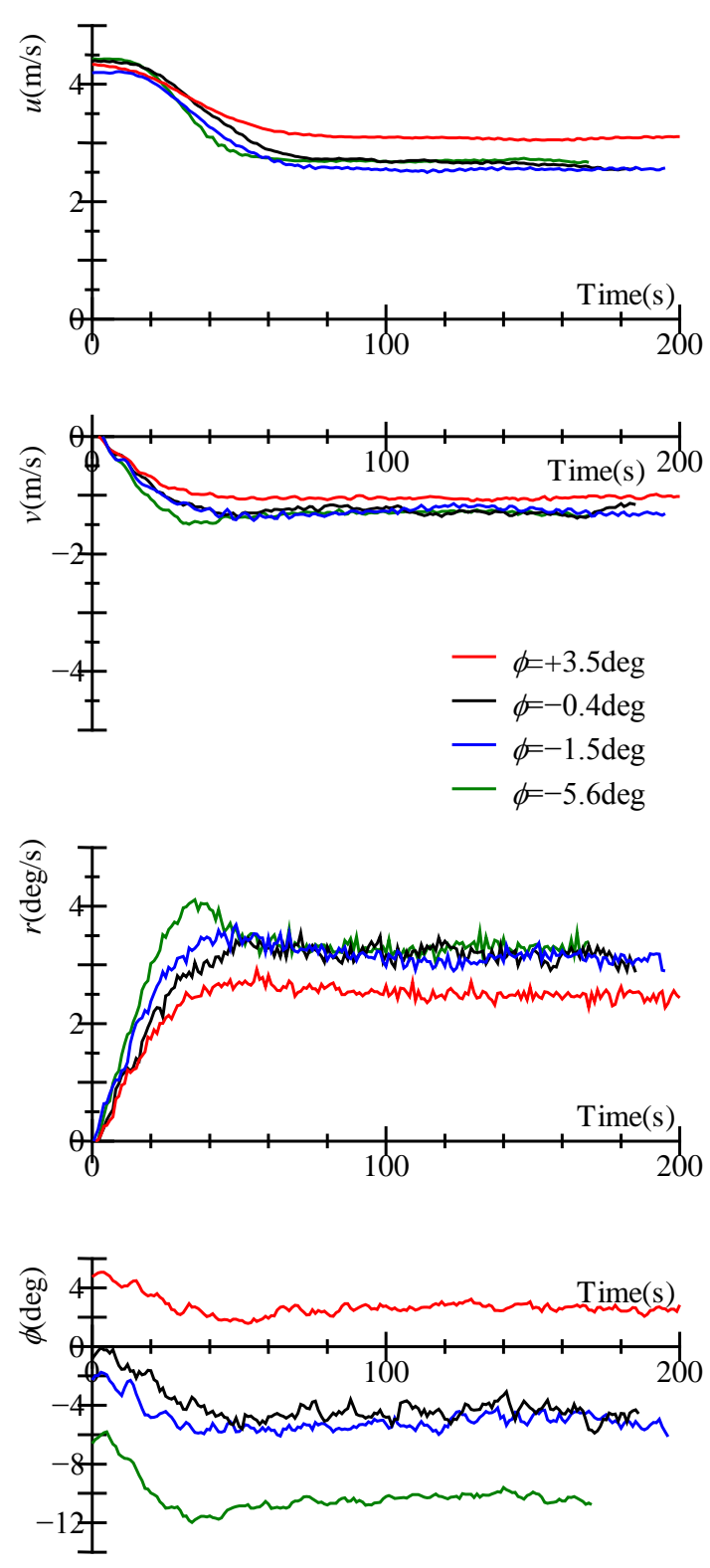

Fig. 11 Comparison of time histories of $u, v, r$ and $\phi$ in turning ( $\delta=+10 \mathrm{deg}$ ) 

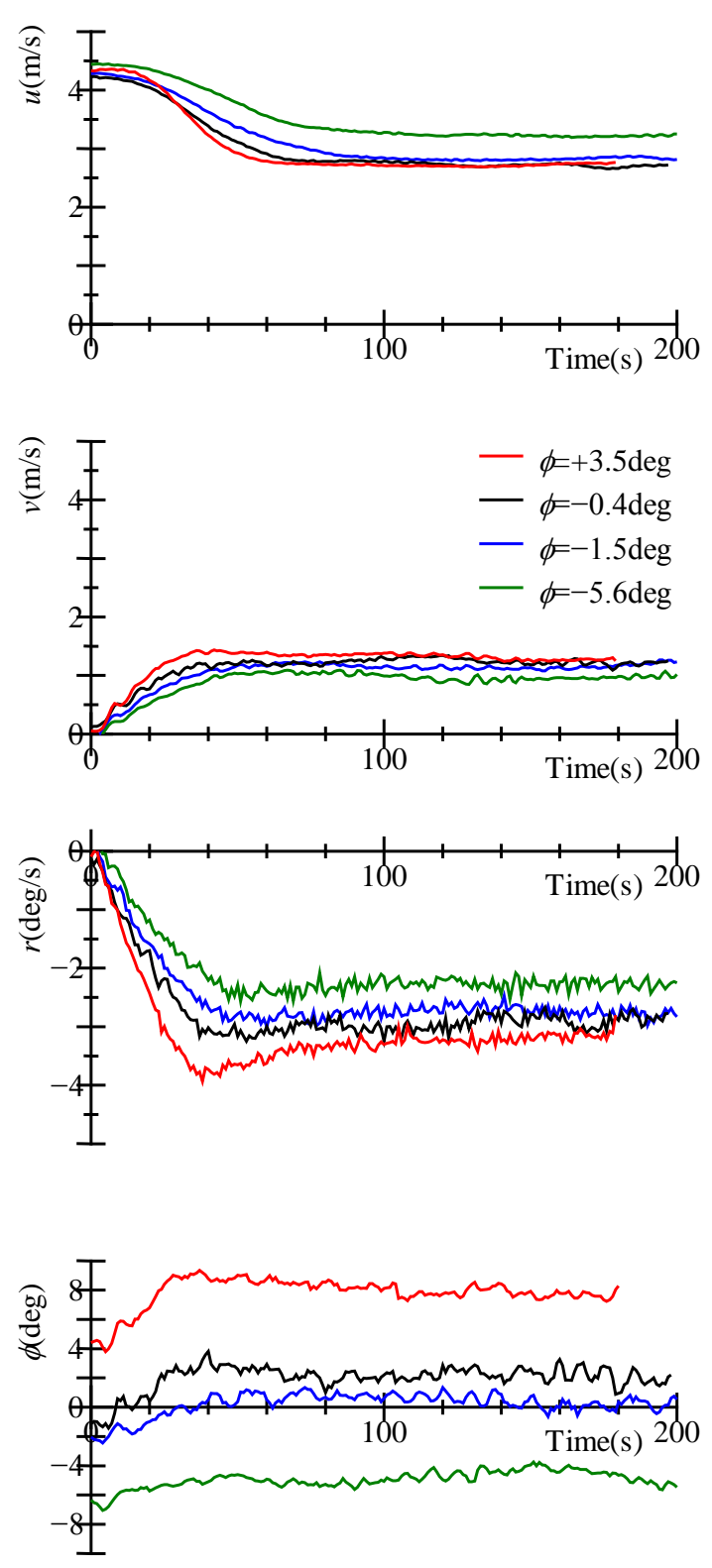

Fig. 12 Comparison of time histories of $u, v, r$ and $\phi$ in turning $(\delta=-10 \mathrm{deg})$

る。首振り角が $10 \mathrm{deg}$ に対して首振り角 $12 \mathrm{deg}$ を比 較するのと、首振り角が $35 \mathrm{deg}$ に対して首振り角 $37 \mathrm{deg}$ を比較することでは、首振り角の大きさが船 の操縦運動に与える影響が違うため、先ほどの結果 のように横傾斜角の影響は目立たなくなると考えら れる。

Fig. 8 に $\phi=-0.4 \mathrm{deg}$ 時の $D_{T} / L_{P P}$ と首振り角の関係 を示す。首振り角の絶対值が小さいところで $D_{T} / L_{P P}$ の大きさの変化量が大きくなっていることがわかる。

Fig. 9 に横傾斜角と $D_{T} / L_{P P}$ の関係を示す。右舷側 に回頭した場合を、赤色の近似線で示し、左舷側に
回頭した場合を、青色の近似線で示している。赤色 の近似線は、どちらも右肩上がりである。これは、 左舷側に横傾斜が付いた時に右舷側への旋回性能が 向上し、右舷側に横傾斜が付いた時に右舷側への旋 回性能が低下（すなわち、左舷側への旋回性能は向 上）することを意味している。青色の近似線は、ど ちらも右肩下がりであり、逆の特徵が表れる。

図の上に位置する $\delta= \pm 10 \mathrm{deg}$ 旋回の近似直線の傾 きと、図の下に位置する $\delta= \pm 35 \mathrm{deg}$ 旋回の近似直線 の傾きを比較すると、 $\delta=+35 \mathrm{deg}$ 旋回では、傾きの絶 対值が $\delta=+10 \mathrm{deg}$ に対して $4 \%$ と小さいまた、 $\delta=-35 \mathrm{deg}$ 旋回では、傾きの絶対值が $\delta=-10 \mathrm{deg} に$ 対し て $8 \%$ と小さい。このことから、首振り角が増大寸 ると横傾斜による $D_{T} / L_{P P}$ の大きさの違いが目立たな くなることがわかる。Fig. 10 に横傾斜角と $A_{D} / L_{P P}$ の 関係を示す。なお、Fig. 10 も Fig. 9 に現れる特徵と 同じ傾向を示している。

Fig. 11 に 4 つの横傾斜の $\delta=+10 \operatorname{deg}$ 旋回試験の時 系列結果を示す。過渡期では、横傾斜角が小さくな るほど回頭角速度 $r$ が大きくなる。よって、前進速 度は他の横傾斜状態よりも早く減少している。右舷 側への旋回の場合、横傾斜角が小さくなるほど旋回 性能は向上寸るため、 $\phi=-5.6 \mathrm{deg} の v, r$ の絶対值が一 番大きくなるという傾向はあるものの、定常旋回時 では、 $\phi=-0.4 \mathrm{deg}$ と $\phi=-5.6 \mathrm{deg} の u, v, r$ は約 $2 \%$ しか違 いがなく、ほぼ同值となっている。これは、 $\phi=-0.4 \mathrm{deg}$ と $\phi=-5.6 \mathrm{deg}$ の $D_{T} / L_{P P}$ の大きさが約 $2 \%$ し違いがな く、ほとんど同じになることを表している。また、 横傾斜が旋回運動によって変化する傾向は、初期傾 斜角を保ったまま一定の間隔でずらした様に見える ことからも同じ特徵を持つことがわかる。

Fig. 12 に 4 つの横傾斜の $\delta=+10 \operatorname{deg}$ 旋回試験の時

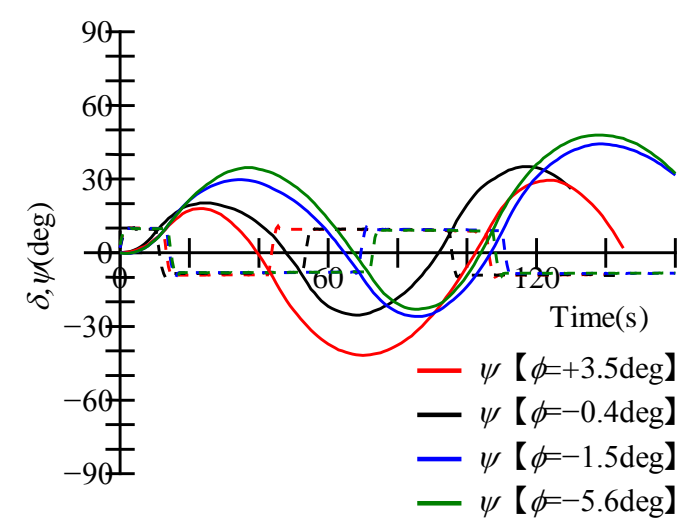

Fig. 13 Comparison of time histories of heading angle and azimuth angles in 10/10Z test 


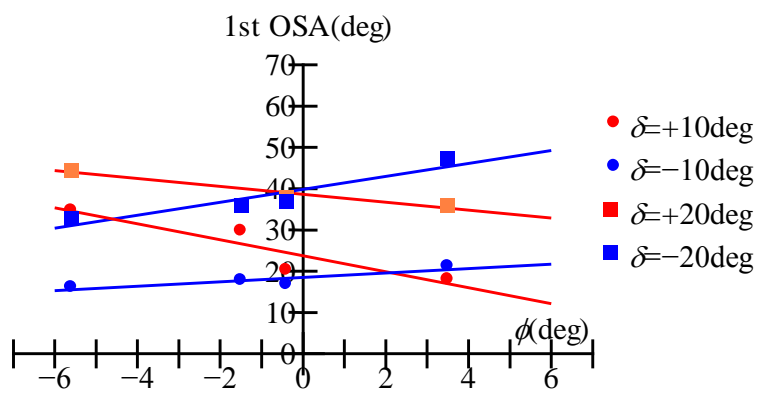

Fig. 14 1st OSA in zig-zag tests versus heel angle

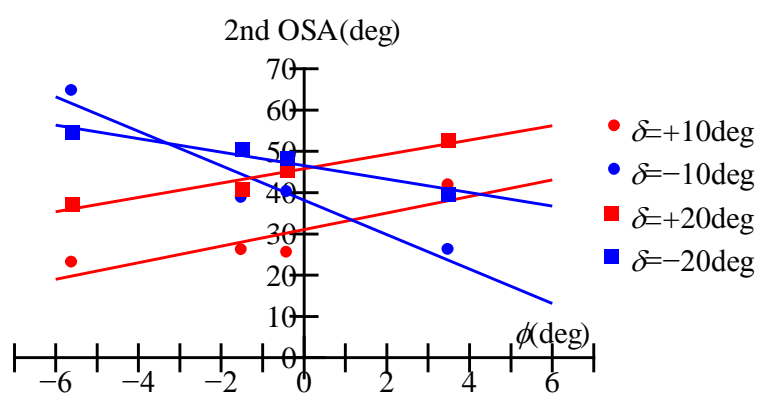

Fig. 15 2nd OSA in zig-zag tests versus heel angle

系列結果を示す。また、Fig. 11 において先ほど説明 した特徵は、Fig. 12 に示す $\delta=-10 \operatorname{deg}$ 旋回の結果でも ほとんど同じように表れている。

\section{$4.3 Z$ 試験}

次に、 $\mathrm{Z}$ 試験の結果を示す。第一行き過ぎ角 (以後 1st OSA) と第二行き過ぎ角 (以後 2nd OSA) によって 保針・変針性能の評価を行う。Fig. 13 は 10/10Z 試験 結果を示している。右舷側に横傾斜が付いた時に $1 \mathrm{st}$ OSA が減少し、2nd OSA が増加している。また、左 舷側に横傾斜が付いた時には逆の特徵が表れている ことがわかる。

Fig. 14 に各横傾斜における 1st OSA を示す。横軸 が横傾斜角、縦軸が 1 st OSA である。赤色の近似直 線は 10/10Z もしくは20/20Z 試験の結果である。丸 印が 10/10Z の結果、角印が 20/20Z の結果を表して おり、どちらも右肩下がりである。これは、右舷側 に横傾斜が付いた時に 1 st OSA が減少し、左舷側に 横傾斜が付いた時に 1st OSA が増加する傾向を表し ている。青色の近似直線は-10/-10Z もしくは-20/-20Z 試験の結果であり、上とは逆の特徵が表れている。

Fig. 15 に各横傾斜角における 2nd OSA を示す。 1st OSA の場合と異なり、赤色の近似直線は、右舷 側に横傾斜が付いた時に 2nd OSA が増加し、左舷側 に横傾斜が付いた時に 2nd OSA が減少する。また、 青色の近似直線は逆の傾向を示す。

これらは、安川・平田が示しているように ${ }^{(1)}$ 、右
舷側に横傾斜したときには、左舷側へ回頭するよう な一定のオフセット舵角をとったような現象が起こ っていると考えることによって説明が付く。

\section{5. 結 言}

強制的に横傾斜を付けて航行する船（「豊潮丸」） の操縦運動を、3 台のK-GPS ${ }^{(2)}$ を用いて実船計測し、 横傾斜状態で航行する船の操縦性能に及ぼす横傾斜 の影響を把握した。まとめると次の通りである。

- 右舷側に横傾斜すると船は左舷側に回頭し、 左舷側に横傾斜すると船は右舷側に回頭する。

- 船体横傾斜はあたかも舵角にオフセットを付 けたように作用し、本船の場合, 横傾斜角 $2 \mathrm{deg}$ は、首振り角約-1deg に相当する。安川・平 田 ${ }^{(1)}$ によると、フェリー船型の場合、横傾斜 角 $3 \operatorname{deg}$ が、舵角約-1deg に相当するとしてお り、そのフェリーと比較すると、本船は横傾 斜に対してヨー運動が誘起されやすい。

- これらの知見は、安川・平田の検討結果 ${ }^{(1)}$ と 定性的に一致した。

\section{謝辞}

実船試験を行うにあたり、多大なるご協力をいた だいた「豊潮丸」の乗組員の方々に感謝の意を表し ます。

\section{参考文献}

（1）安川宏紀、平田法隆 : 横傾斜状態で航行する船 の流体力微係数と操縦性、日本船舶海洋工学論 文集第 17 号、2013.6.

（2）平田法隆、松村和昌：K-GPS による OP 級ヨ ツトの運動計測、日本航海学会論文集 第 124 号、2011.3.

（3）平田法隆、浮田寛之、安川宏紀 : 練習船「豊潮 丸」の操縦性に及ぼすトリム影響、日本航海学 会論文集 第 126 号、2012.3. 